\title{
ISSN: $0971-4456$
}

Asian Journal of

Dairy and Food Research

Formerly : Joumal of Dairying, Foods and Home Sciences

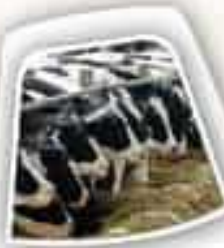

AGRICULTURAL

RESEARCH

COMMUNICATION

CENTRE

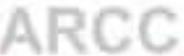

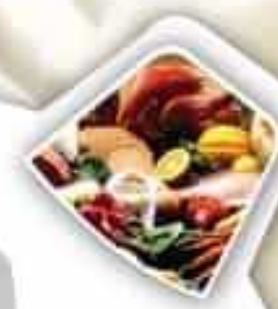




\section{ASIAN JOURNAL OF DAIRY AND FOOD RESEARCH}

\section{Editorial Board}

\section{Chief Editor \\ Associate Chief Editor}

Editor

Associate Editor

Managing Editor

Harjinder Singh, New Zealand

Sushil Kumar, Gurgaon

D.C. Sen, Mohanpur

A.S. Bawa, Mysore

V.B. Singh, Udaipur

M.K. Salooja, Delhi

G.R. Patil, Karnal

Amarjit Kaur, Ludhiana

Kamal G. Nath, Bangalore

Aruna Palta, Raipur

D. Vijayalakshmi, Bangalore

V.R. Sinija, Thanjavur
G.S. Rajorhia, Ex. Professor

National Dairy Research Institite., Karnal

Tanweer Alam, Joint Director,

Indian Instt. of Packaging, New Delhi.

M.P. Gupta, Ex. Professor \& Head, Dairy Science, Veterinary University, Mathura.

Eram S. Rao, New Delhi.

R. D. Goel,

A.R.C.C., Karnal.

\section{$\underline{\text { Members }}$}

Alok Jha, New Delhi

S.K. Kanawjia, Karnal

P.C. Sarkar, Ranchi

Jashbhai B. Prajapati, Anand

Dinesh Chandra Rai, Varanasi

D.B. Puranik, Kalaburagi

Narinder Singh, Ropar

A.G. Bhadania, Anand

K. Jayaraj Rao, Bangalore

H.K. Sharma, Longowal

N. Lakshmidevi, Secunderabad

Correspondence Address :

Managing Editor

Agricultural Research Communication Centre

1130, Sadar, Karnal - 132 001, India

Phone : +91 9255540308, E-mail : contact@arccjournals.com; editor@arccjournals.com

Website : www.arccjournals.com 


\section{ASIAN JOURNAL OF DAIRY AND FOOD RESEARCH}

Vol. 35, No. 2

NAAS Rating 3.88

June, 2016

CONTENTS

Page No.

\section{DAIRY SCIENCE}

High pressure processing technology in dairy processing: A review

V. Dhineshkumar, D. Ramasamy and M. Siddharth.

Composition, nutritional and therapeutic values of goat milk: A review

Alok Kumar Yadav, Jitendra Singh and Shiv Kumar Yadav.

Influence of Modified Atmosphere Packaging (MAP) on textural properties of Mozzarella cheese during refrigeration storage

Tanweer Alam, N.C Saha, Aastha Bhardwaj and G.K. Goyal. 103

\section{FOOD SCIENCE}

Physicochemical changes in GRAS coated and gamma radiated water chestnut (Trapa bispinosa Roxburg) during ambient storage in different storage structures Nazia Hussain, S.S. Shukla, Brijlata Dubey and MD. Aziz Ahmed...

Effect of pectin coating on colour and quality of dehydrated pineapple during storage

C.S. Saini and H.K. Sharma.

Effect of vegetables gums on proximate, functional, optical and sensory attributes of catfish nuggets during chilled storage P.C. Sarkar, Upali Sahu, P.K. Binsi and Natasha Nayak.

Effect of autoclaving and cooling on resistant starch formation in rice starch

Lilia-Baby, K.T. Suman, S. Krishnan and V. Indira.

Effect of incorporation of Paneer whey on dough characteristics and organoleptic attributes of milk bread

Aditi Kakan, Sudhakar Changade and Santosh Chopde.

Nutritional status of university faculty as influenced by the nutrient intake

Ramandeep Kaur and Sonika Sharma.

Study of inhibition of browning of clarified banana juice

A.R. Tapre and R.K. Jain. 
Study on effect of fermentation to the quality parameter of cocoa bean in Indonesia

Mulono Apriyanto, Sutardi, Supriyanto and Eni Harmayani...........................................................160

Influence of storage temperatures on the protein content

of french beans (Phaseolus vulgaris $\mathrm{L}$ )

Ex, Manpreet Kaur, Satish Kumar Gupta, T.C. Mittal and S.R. Sharma..........................................164

Quality assessment of mustard oil in deep fat frying

Prakash Kumar Nayak, Uma Dash and Kalpana Rayaguru............................................................168

Formulation of osmo- dehydrated cashew apple (Anacardium occidentale $\mathbf{L}$.)

C. Mini and S.S. Archana..

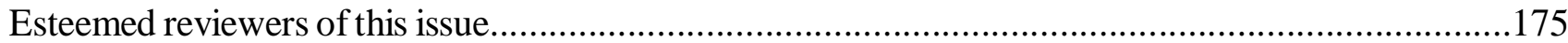

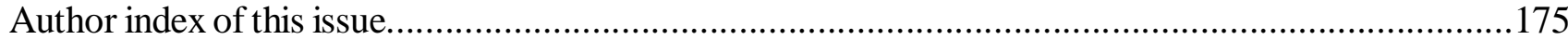

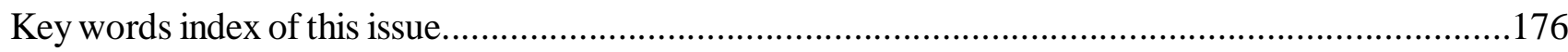

www.arccjournals.com 


\section{ESTEEMED REVIEWERS OF THIS ISSUE}

Anuradha Dutta, Pantnagar

D. D. Wadikar, Mysore

Dwaipayan Bardhan, Izatnagar

H.K. Sharma, Sangrur

Haresh Sharma, Sangrur

K. D. Sharma, Palampur

K. Uma Maheswari, Rajendra Nagar

K.D. Chavan, Dhule

Madhav R. Patil, Latur
Neeta Chopra, Agra

Nirmala B. Yenagi, Dharwad

P. Ashlesha, Koti

P. C. Sarkar, Ranchi

Rahul C. Ranveer, Kolhapur

S. D. Shivakumar, Coimbatore

Sangita Chahal, Hisar

Subhashini Verma, Ludhiana

V.M. Salunke, Nagpur

\section{AUTHOR INDEX OF THIS ISSUE}

A.R. Tapre.

Aastha Bhardwaj.

Aditi Kakan.

Alok Kumar Yadav.

Brijlata Dubey..

C. Mini

C.S. Saini

D. Ramasamy

Eni Harmayani.

Ex, Manpreet Kaur.

G.K. Goyal.

H.K. Sharma

Jitendra Singh

K.T. Suman..

Kalpana Rayaguru.

Lilia-Baby......

M. Siddharth

MD. Aziz ahmed

Mulono Apriyanto.

N.C Saha.

Natasha Nayak

Nazia Hussain.
.155

103

.143

.96

111 Ramandeep Kaur.

.172 S. Krishnan 120

. .87

.160

164

103

.120

.96

.137

.168

137

..87

.111

160

103

.130

.111

P.C. Sarkar.

P.K. Binsi.

S.R. Sharma

S.S. Archana

S.S. Shukla Santosh Chopde. Sonika Sharma. Supriyanto.

Sutardi.

T.C. Mittal.

Tanweer Alam.. Uma Dash. Upali Sahu.

V. Dhineshkumar. 130 130 168 155 .149 .137 172 .111 .143

Satish Kumar Gupta. .164 Shiv Kumar Yadav.. . .96 .149 Sudhakar Changade. .143 160 .160 164 103 .168 .130 ...87 .137 
24 hour recall method.

Acidity.

Ascorbic acid.

Autoclaving.

Binder.

Browning Index

Browning

Cashew apple

Clarified banana juice

Coating.

Cocoa beans

Cold processing.

Colour kinetics.

Dairy products.

DIET CAL

Dough characteristics

Fermentation indexs

Fermentation.

Fish nuggets

Free fatty acid

French beans.

Gamma radiation.

Gelatinization

Goat milk composition

GRAS chemical.

Guar gum

Gum Acacia

Honey.

Hydrostatic pressure

Isostatic

MAP.

Medicinal properties
149 Milk bread. 143

160 Minimally processed. .87

155 Mixed culture microbies. .160

137 Mozzarella cheese.. 103

130 Nutrient intake. 149 155 155 172 155 120 160 .87 120 .87 149 143 160 160 130 168

164

Nutritional value. $.96,111$

Organoleptic attributes of bread. 143 Osmo-dehydration.

Packaging. 164

Paneer whey......................................................143

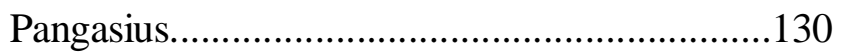

P-anisidine........................................................ 168

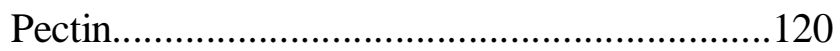

Percent adequacy.................................................149

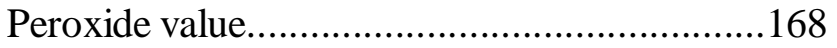

$\mathrm{pH}$

Physical properties..............................................111

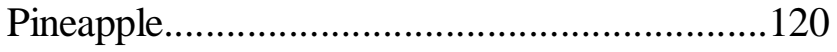

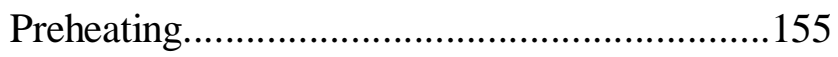

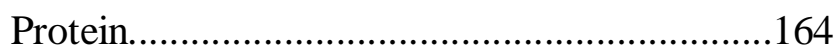

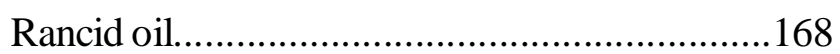

Recommended dietary allowances...................149

Refrigeration storage..............................................

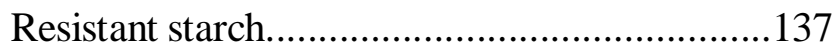

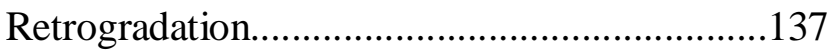

Shelf life..................................................103,164

Storage structures.................................................111

Storage..................................................120,164

Textural properties.............................................103

Texturising agent ...............................................130

Therapeutic properties............................................96

.96 Water chestnut...................................................111 


\title{
Study on effect of fermentation to the quality parameter of cocoa bean in Indonesia
}

\author{
Mulono Apriyanto*, Sutardi ${ }^{1}$, Supriyanto ${ }^{1}$ and Eni Harmayani ${ }^{1}$ \\ Department of Food Technology, \\ Indragiri of Islam University, Indragiri Hilir Riau, Indonesia \\ Received: 02-02-2016 Accepted: 03-03-2016
}

DOI: 10.18805/ajdfr.v35i2.10724

\begin{abstract}
Most cocoa beans in Indonesia are traditionally produced by farmers using non fermented and sun drying method. The quality of cocoa beans produced by farmer in yogyakarta may be improved by the fermentation method. However, it needs optimization for best fermentation process. The aims of the study was to improve quality of cocoa bans by fermentation of sun dried cocoa beans. The characteric fermented cocoa beans was determined by maesuring changes $\mathrm{pH}$, acidity and fermentation indexs of cocoa beans during fermentation. This study used preconditioned cocoa beans to resamble obtain from the farmer. Preconditioning was done in order to get $15 \%$ mouisture content of pulp at same level as moisture content of pulp from traditional process. Before fermentation, therefor sun dried cocoa beans was rehydrated to obtain a moisture content of pulp similiar to fresh beans pulp, and then fermentation was conducted for 120 hours. Changes in acidity and fermentation indexs of cocoa beans during fermentation were measured. The fermentation process used 3 level treatment i.e. control (without inoculum), mixed culture of microbies added at the begining fermentation. The result show all cocoa beans acidity increase during fermentation from $4,48 \%$ to $6,45 \%$ for control, 4,64\% to 6,39\% for addition of inoculum at begining of fermentation and from $4,45 \%$ to $6,59 \%$ for addition of inoculum at the begining and midle of fermentation and fermentation indexs of cocoa beans increase for all level of inoculum addition i.e. 0,31 to 0,88 for control, 0,32 to 0,99 for addition of inoculum at the beginning fermentation and 0,33 to 1,03 for addition of inoculum at the beginning and midle of fermentation. The study indicated that addition of mix culture microbies in fermetation improved the quality of cocoa beans that characterized by $\mathrm{pH}$, acidity and fermentation indexs of cocoa beans.
\end{abstract}

Key words : Acidity, Cocoa beans, Fermentation, Fermentation indexs, Mixed culture microbies, pH.

\section{INTRODUCTION}

Post-harvest handling of fresh cocoa beans is usually impemented in 2 methods. Fristly, the cocoa beans are fermented traditionally and dried by artificial drying. Second the cocoa beans are directly sun dried for several days without fermentation any more. According to the Bureau of Statistics Data (Anonymous, 2013) that the dried cocoa production in 2013 reached 5.45 million tonnes and \pm dry unfermented cocoa beans of \pm 38.5000 tons. Dry unfermented cocoa beans consist of sun dried cocoa beans and dry half-fermented cocoa beans produce by cocoa farmer. Indonesian cocoa beanas farmers produce \pm as $93 \%$ of cocoa beans by simple method i.e. washing cocoa beans and it was directly dried by sun drying method without fermentation,. While 7\% of dry cocoa beans are produced by either the private company or national plantation company using fermentation method (Anonymous, 2013).

Fermented of cocoa beans is essentially a process to breakdown sugar compound in the pulp into organic acids such as citric acid and it was carried out by microbies (Camu, et al., 2008, (Ardhana and Fleet, 2003). The produce organic acids during fermentation will induce enzymatic reactions in the beans cotyledon, causing biochemical changes. Most of the are compound that give specific flavor, taste, and color of the cocoa beans (Biehl, et.al, 1985, Afoakwa, et.al, 2014). The fermentation process was carried out by using wood boxes for 5-7 days incubation and sttired reversaslly for every 2 days. The cocoa beans without fermentation will create bitter taste, astringcy, and will not produce distinctive aroma of chocolate after roasting process (Schwan and Wheals, 2004).

Dry beans had lost most of the water content and several compound as substrate of microbies. The water content of cocoa beans during fermentation was utilized for enzymatic reactions in the beans cotyledon and also for microbial growth in cocoa beans pulp (Schwan and Wheals, 2004). Water will bring the enzyme to the substrate that is in the beans cotelydon, so that the hydrolysis and oxidation of the precursor of flavor, color, and aroma of the cocoa beans occured. The water content of cocoa beans required in the fermentation of cocoa is more than $35 \%$. Substrate in the fermentation of cocoa beans are sugar that is available in cocoa beans pulp and coverted to organic acid such as citric acid. Organic acid will diffuse into the beans cotelydon

*Corresponding author's e-mail: mulonoapriyanto71@gmail.com. 'Department of Food and Agriculture Product Technology, Faculty of Agriculture Technology, Gadjah Mada University, Yogyakarta, Indonesia. 
and induces the enzymatic reactions to form precursor of flavor, aroma and color (Afoakwa et al., 2014). Soaking of un-fermented cocoa beans was done to rehydration of cocoa beans before fermentation. Research on fermented dry cocoa beans using unferrmented cocoa bean was done successfully in the engineering lab PAU, UGM., The aimed study to determine changes in the chemical properties of fermented dry cocoa beans drying.

\section{MATERIALS AND METHODS}

Preparation of cocoa beans : Cocoa beans used were taken from ripe cocoa pods, which was a yellow or orange fruit that sounds hollow when tapped. Friuts without washing was cleaved to remove the beans cotyledon and dried in the cabinet dryer at $40{ }^{\circ} \mathrm{C}$, until the moisture content of the beans reached to $\pm 15 \%$. Hundred (100) g of dry beans was soaked in $60 \mathrm{ml}$ distilled water at room temperature for 5 days (120 hours). Soaked ccocoa beans were susequently fermented at room temperature for 5 days as well. Changes of total sugar, reducing sugar, $\mathrm{pH}$, acidity, index of fermentation were determined and a succession of microbes during fermentation was also determined and it was compared to fermentated fresh cocoa beans.

Preparation of the pulp samples: The pulp was manually separated from the beans by rubbing the beans (with adhering pulp) between fingers and squeezing the pulp into clean sample bag.

Preliminary analysis: Preliminary analysis was conducted to determine the water content and reducing sugar of pulp and cocoa beans before and after drying. The water content of the cocoa beans is determined using thermogravimetric method, while reducing sugar content of the wet and dried pulp was analyzed by using Nelson-Somogy Method (Sudarmadji et.al., 1997).

Fermented cocoa beans: First fermentation, $100 \mathrm{~g}$ of fresh cocoa beans was fermented at room temperature for 5 days. Second fermentation, $100 \mathrm{~g}$ un-fermented cocoa beans was soaked in $60 \mathrm{ml}$ of distilled water before fermentation and then they were fermented at room temperature for 5 days.

Experimental design: The experimental design used for the study was Ramdomized Complete Block Design (RCBD). The variable factors were cocoa treatments (fresh and sun dryed cocoa beans) and fermentation time (0; 3 and 6 days). The $\mathrm{pH}$, non-volatile (titratable) acidity, reducing sugars, fermentation index and total microbes (total plate count) were studied. All statistical analysis were performed using SPSS 13.00 statistical package program (2002). The data were analyzed by analysis of variance (ANOVA). If there is signicant different between treatmets, therefore it was followed by Duncan Multiple Range Test (DMRT) using $0.05 \%$ significancy.

pH and non-volatile (titratable) acidity: $\mathrm{pH}$ and nonvolatile (titratable) acidity of the pulp were determined using the method as described by Nazaruddin et al. (2006) with slight modifications. Ten (10) $\mathrm{g}$ of the pulp was homogenized in $90 \mathrm{ml}$ of hot distilled water, stirred manually for $30 \mathrm{~s}$ and filtered using Whatman filter paper No. 40 and cooled to $20-25^{\circ} \mathrm{C}$. Twenty five $(25) \mathrm{ml}$ aliquot of the resulted filtrate was pipetted into a beaker glass and the $\mathrm{pH}$ was measured using a pH meter (Mettler Toledo MP 230), and calibrated with buffers at pH4.01, 7.00 and 9.21. A further $10 \mathrm{ml}$ aliquot was used to determine acidity by titration to an end point $\mathrm{pH}$ of 8.1 with $0.1 \mathrm{~N} \mathrm{NaOH}$ solution and the values were reported as moles of sodium hydroxide $(\mathrm{NaOH})$ per $100 \mathrm{~g}$ of sample.

Fermentation index determination: Fermentation index of cocoa beans were determined using the method as described by Misnawi et al. (2002). Five hundred (500) $\mathrm{mg}$ of defatted cocoa powder were weighed into a $125 \mathrm{ml}$ conical flask containing a mixture of $50 \mathrm{ml}$ of methanol:hydrochloric acid (97:3), the mixture was cooled at $8 \pm 2{ }^{\circ} \mathrm{C}$ in a refrigerator for $16-18 \mathrm{~h}$. A clear extract was obtained by filtration through a Whatman filter paper No. 1. Fermentation index was calculated, based on the ratio of the absorbance at 460 $\mathrm{nm}$ to the absorbance at $530 \mathrm{~nm}$.

\section{RESULT S AND DISCUSSION}

The $\mathrm{pH}$ of sun dried cocoa beans has been reported to range between $5-5.7$ and $\mathrm{pH}$ of pulp between $6-6.2$ (Figure 1). During the first two days of fermentation, the $\mathrm{pH}$ cocoa beans was recorded $5.7 \pm 0.1$, and decreased to $3.8 \pm 0.1$ in $48 \mathrm{~h}$ fermentation, and at the end of fermenation was slight increased to $4.5 \pm 0.2$. The beginning of fermention, however, $\mathrm{pH}$ of pulp was $4.5 \pm 0.1$, an slightly increased to $6 \pm 0.1$ during fermentation (Figure 1). Fermentation of cocoa beans caused significant $(\mathrm{p} \leq 0.05)$ increasesed the acidity levels of cocoa beans, and reached at maximum level after 48 fermentation. After which the titratable acidity decreased considerably until the end of fermentation period, and this was noted for all treatments (Figure 2). The interaction between fermentation time and prepared of cocoa beans (with and withoud fermentation) gave significant effect ( $\mathrm{p} \leq 0.05)$ on acidity level of pulp. The fermentation index was close to 1 as

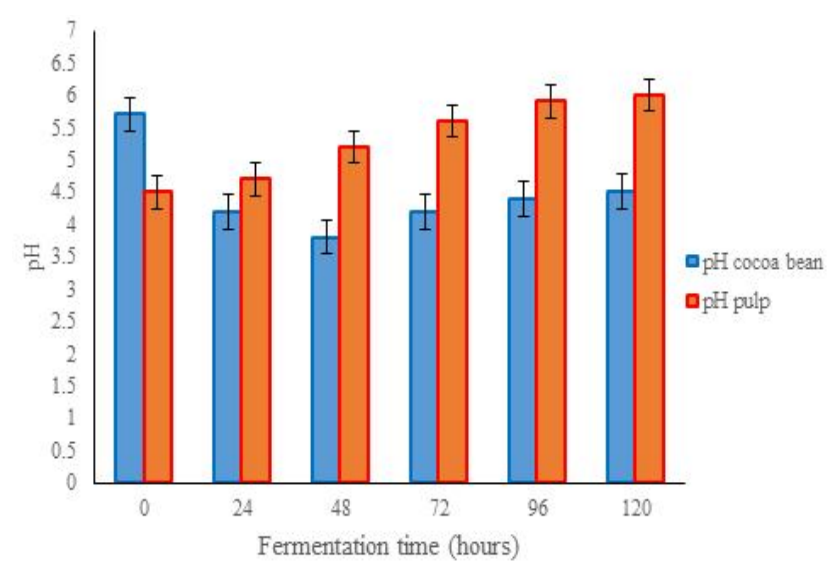

Fig 1: Changes in $\mathrm{pH}$ during cocoa beans fermentation. 


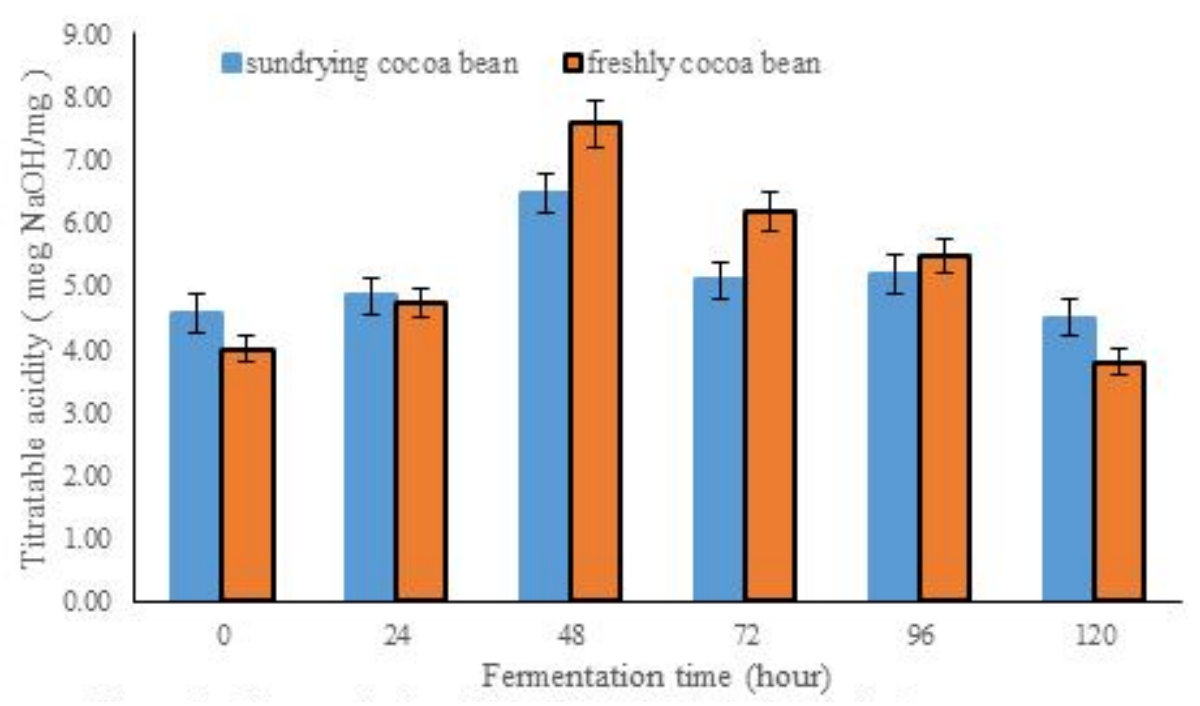

Fig 2: Changes in titratable acidity of cocoa beans during fermentation

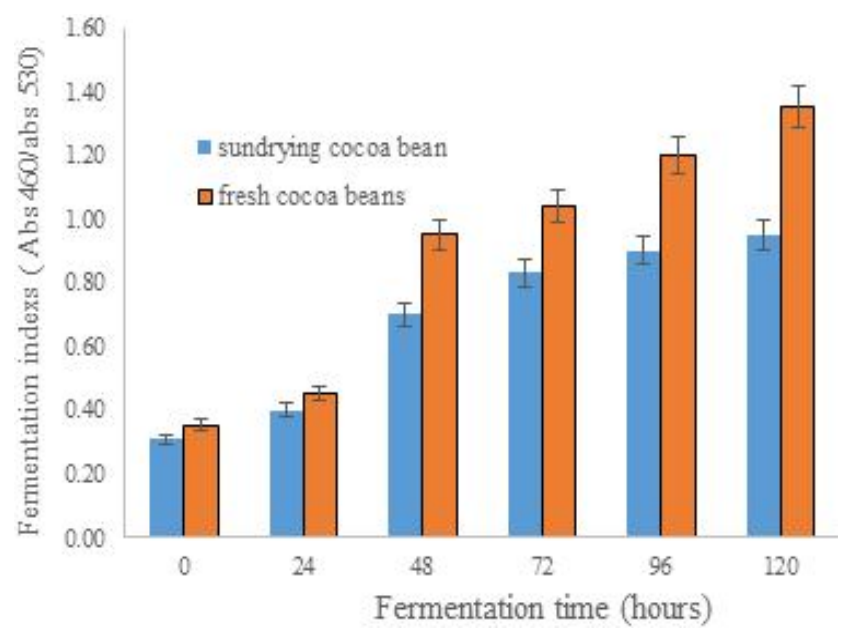

Fig 3: Change fermentation indexs cocoa bean during fermentation

indication for good fermentation. Comparison between dry cocoa beans obtained from treated cocoa beans and fermented fresh cocoa beans is showed in Figure 3. Fermentation indexs of sundried cocoa beans was $0.35 \pm 0.1$, and increased to $1.35 \pm 0.1$. While fermentation index of dry fresh cocoa beans was $0.31 \pm 0.1$, slightly increased to $0.95 \pm 0.1$ after $120 \mathrm{~h}$ fermentation.

Changes in $\mathbf{p H}$ profile of cocoa beans: The acidity cocoa beans at the beginning of fermentation was moderatlo low $(3-4)$. It was due to the content of citric acid, and it was preferable to growth of yeast. However, as fermentation on going, the dominant microbes was yeasts with good pectinolytic activity, and they degraded cocoa beans pulp to produce organic acids especially citric acid. Such citric acid will change fermenation condition that preferable to bacteria growt. This explained why the $\mathrm{pH}$ of pulp changed from 5.20.10 (after $48 \mathrm{~h}$ fermentation) to $5.6 \pm 0.20$ (after $72 \mathrm{~h}$ fermention). While $\mathrm{pH}$ of cocoa beans descreased from 5.7 \pm 0.1 to $3.8 \pm 0.1$ (after $24 \mathrm{~h}$ fermentation) and slightly increased to $4.5 \pm 0.10$ (after $72 \mathrm{~h}$ fermentation). Once the environment of fermentation became more aerobic, so that the lactic acid bacteria (LAB) would dominate fermentation process and converting the intermediate metabolites into lactic acids. At the latter stage of fermentation, acetic acid bacteria $(\mathrm{AAB})$ oxidized the ethanol produced by yeasts and LAB into acetic aceid and further more to carbon dioxide $\left(\mathrm{CO}_{2)}\right.$ and water. Nevertheless, the acetic acid was highly volatile and seldom accumulated under aerobic condition. Unlikely, the $\mathrm{pH}$, the titratable acidity were more appropriate indicator to measure the total acid level in any fermentation process and usually both parameters are negatively correlated. According to Beckett, (2009), the synthesis of lactic acid was very common among lactic acid fermentation, especially cocoa beans fermentation that carried out under anaerobic condition. The temperature rose steadily from 27 to $40^{\circ} \mathrm{C}$ (fresh cocoa beans) and from 26 to $38^{\circ} \mathrm{C}$ (sundried cocoa beans), respectively after the cocoa fermentation.

The steady increase on the temperature may be associated to the release of heat from cocoa biomass during the fermentation process. Initially, the yeasts were dominan species that utilize the available fermentable substrate (such as sugar) before converting them into ethanol and further to acetic acid via microbial succession. The conversion of fermentable substrate into desired metabolite by-products was performed exothermically, and hence it assisted to the increase of temperature (Schwan and Wheals, 2004).

Changes in non-volatile (titratable) acidity of cocoa pulp: During fermentation of cocoa beans, microorganisms breakdown the sugars in the pulp resulting in the production of alcohols and organic acids sucah as acetic acid -which then diffuse into the beans. Production of organic acids in the pulp is important in cocoa beans fermentation as these acids diffuse into the beans and subsequently induce the important biochemical reactions leading to well fermented 
cocoa beans. The acidity level was highest at $48 \mathrm{~h}$ of fermentation as most of the pulp sugars were probably degraded into alcohols and then oxidized to acetic acid by acetic acid bacteria within $48 \mathrm{~h}$ of fermentation. Ardhana and Fleet (2003) reported that highest concentration of acetic acid (10 mg/g sample) in cocoa pulp occurred at $72 \mathrm{~h}$ (3 days) of fermentation. Acidity levels decreased after 3 days fermentation, it was due to most of the acid produced have diffused into the beans. Again, as the pulp volume reduced, there was improvement in aeration in the fermentation of biomass (pulp) leading to the evaporation of volatile acids such as acetic acid.

This might be due to the fact that reduced pulp volume per beans, caused reduction of pulp sugar content and thus, increased micro-aeration within the pulp. The decreasing of sugar content in pulp as result of yeasts activity during fermentation and consequently produced alcohol and acetic acid in the pulp (Biehl et al., 1985). This suggested that cocoa beans preconditioning could be effectively employed to reduce acidity levels in cocoa beans during fermentation.
Fermentation index: The figures 3 shows that until the end of fermentation, however fermentation index of fermented sundried beans was not met, it was presumably because the temperature of fermentation was not reached. It was due to total population of microbes was not satisfactory for encouragemnet of fermentation process.

\section{CONCLUSSION}

The results of this study may be concluded that during drying of cocoa beans (coverd by pulp) did not cause the microbe dead, so when cocoa beans were rehydrated the microbes were still surfive. This eveident may be seen in the succession of microbes that occured with yeast (S. ceriviiae) population xchanged by LAB and followed by $\mathrm{AAB}$ during fermentation. The quality of sundried un-fermented cocoa beans compared with fresh fermented cocoa beans have in common. Fermentation index of sundried un-fermented cocoa beans was highest i.e. 0.95 . From whole fermentation quality data it can be said that the quality of sunried cocoa beans may be improved through fermentation. The fermentation process of cocoa beans may be speed up by utilization of inoculum in order to improve the quality dry cocoa beas

\section{REFERENCES}

Afoakwa E. O., Kongor, J.E., Takrama and J. Badudu, A. S. (2014). Changes in nib acidification and biochemical composition during fermentation of pulp pre-conditioned cocoa (Theobroma cacao) beans. Internasional Food Research Journal, 20: 1843-1853.

Anonymus. (2013). Produksi Perkebunan Besar menurut Jenis Tanaman, Indonesia. from wibsite http://www.bps.go.id. acces in Mei 2015

Ardhana M.M. and dan Fleet, G. (2003). The microbial ecology of cocoa bean fermentations in Indonesia. International Journal of Food Microbiology, 86:87-99.

Biehl, B., Br unner, E., Passern, D., Quesnelh, V. C. and dan Adomako, D. (1985). Acidification , proteolysi s and flavour potential in fermenting cocoa beans, Journal Food dan Science 3 :583-598.

Beckett S.T., (2009). Industrial chocolate manufacture and use. 4th, Wiley-Blackwell, United Kingdom

Camu, N., Winter, T. De, Addo, S. K., Takrama, J. S., Bernaert, H.and Vuyst, L. De. (2008). Fermentation of cocoa beans/ : influence of microbial activities and polyphenol concentrations on the flavour of chocolate, Journal of the Science of Food and Agriculture 88 : 2288-2297.

Misnawi, Jinab, S., Nazamid, S. and Jamilah, B. (2002). Activation of remaining key enzymes in dried under-fermented cocoa beans and its effect on aroma precursor formation. Food Chemistry, 78: 407-417.

Nazaruddin, R., Seng, L. K., Hassan, O. and Said, M. (2006). Effect of pulp preconditioning on the content of polyphenols in cocoa beans (Theobroma Cacao) during fermentation. Industrial Crops and Products, 24: 87-94.

Schwan, R. F. and Wheals, A. E. (2004). The microbiology of cocoa fermentation and its role in chocolate quality. Critical Reviews in Food Science and Nutrition, 44: 205-221.

Sudarmadji, S., Bambang and H dan Suhardi. (1997). Prosedur analisa bahan pangan, liberty pres. yogyakarta. 